\title{
EVALUATION OF THE COAGULANT CAPACITY OF STARCH OBTAINED FROM TOPOCHO PELIPITA PLANTAIN CLONE (Musa ABB) FOR TURBIDITY AND COLOR REMOVAL IN RAW WATERS
}

\author{
Diego Felipe TIRADO ${ }^{1 *}$, Adriana Patricia HERRERA ${ }^{1}$ and Diofanor ACEVEDO CORREA ${ }^{2}$
}

${ }^{1}$ Facultad de Ingeniería, Universidad de Cartagena. Avenida Consulado, calle 30, 48-152, Cartagena de Indias, Colombia

${ }^{2}$ Grupo de Investigación en Nutrición, Salud y Calidad Alimentaria, Universidad de Cartagena, Avenida Consulado, calle 30, 48-152, Cartagena de Indias, Colombia

*Corresponding author: dtiradoa@unicartagena.edu.co

(Received November 2015; accepted May 2016)

Key words: native starch, acetylated starch, degree of acetylation, coagulation, flocculation

\begin{abstract}
Flocculation and coagulation of organic material contained in raw water samples were evaluated by using starch as coagulation agent. The starch was obtained from topocho pelita (Musa ABB) plantain clone, which is grown in the south area of the department of Bolivar, Colombia. Native starch (NS) was chemically modified with acetic anhydride obtaining an $18.3 \%$ degree of acetylation (low acetylated starch, LAS) and $23.7 \%$ (high acetylated starch, HAS). The chemical structure of these biomaterials was analysed by Fourier transform infrared (FTIR) spectroscopy. Characteristic peaks were observed at $1350 \mathrm{~cm}^{-1}$ (C-O stretching) and $950 \mathrm{~cm}^{-1}$ (C-O-C bending). Scanning electron microscopy (SEM) was used to determine morphology and size of the starch samples. Elongated grain shapes with sizes of $37 \pm 8 \mu \mathrm{m}(\mathrm{NS}), 35 \pm 11 \mu \mathrm{m}$ (LAS) and $307 \pm 85$ $\mu \mathrm{m}$ (HAS) were observed through this technique, suggesting a relationship between the degree of acetylation and the agglomeration of grains. Analysis of variance indicated that concentration of the starch samples is the only factor, which has a statistically significant effect on the response variables (color and turbidity) at a $95 \%$ confidence level. Color removal capacities of $94 \%, 93 \%$ and $89 \%$ were estimated using the NS, LAS and HAS samples, respectively, at a concentration of $200 \mathrm{mg} / \mathrm{L}$. Additionally, a turbidity removal capacity of $96 \%$ was estimated for the NS sample, which compares very well with the $95 \%$ turbidity removal capacity obtained from the acetylated starches. The latter indicates that native starch presents suitable properties to be used as coagulation agent for water treatment.
\end{abstract}

Palabras clave: almidón nativo, almidón acetilado, grado de acetilación, coagulación, floculación

\section{RESUMEN}

La floculación y la coagulación de materia orgánica presente en muestras de aguas crudas fueron evaluadas usando como agente coagulante almidón obtenido a partir del plátano del clon topocho pelipita (Musa ABB) cultivado en el sur del departamento de Bolívar, Colombia. La capacidad de coagulación del almidón nativo (NS, por sus siglas en inglés) fue comparada con almidón modificado químicamente con anhídrido 
acético con grados de sustitución del $18.3 \%$ (LAS, por sus siglas en inglés) y $23.7 \%$ (HAS, por sus siglas en inglés). Espectroscopía de infrarrojo (FTIR, por sus siglas en inglés) fue usada para determinar la estructura química de estos biomateriales, se observaron vibraciones en $1350 \mathrm{~cm}^{-1}$ (estiramiento C-O) y $950 \mathrm{~cm}^{-1}$ (flexión C-O-C). Microscopía electrónica de barrido (SEM, por sus siglas en inglés) se usó para determinar la morfología y el tamaño de las muestras de almidón, se observó una forma de granos alargados, los cuales exhibieron tamaños de $37 \pm 8 \mu \mathrm{m}$ (NS), $35 \pm 11 \mu \mathrm{m}$ (LAS) y $307 \pm 85 \mu \mathrm{m}$ (HAS). Esto sugiere que el aumento en grados de sustitución puede ocasionar la aglomeración de los granos y su consiguiente aumento de tamaño. El análisis de varianza indicó que sólo la concentración de las muestras de almidón tiene efectos estadísticamente significativos en las variables de respuesta de color y turbidez a un nivel de confianza del $95 \%$. A partir de esta evaluación se estimó para una concentración máxima de $200 \mathrm{mg} / \mathrm{L}$ de almidón una capacidad de remoción del color del $94 \%$ para la muestra NS, $93 \%$ para LAS y $89 \%$ para HAS. En el caso de remoción de turbidez, se estimó una capacidad del $96 \%$ para la muestra NS y $95 \%$ para los almidones acetilados, por lo cual se concluye que el almidón nativo presenta excelentes propiedades para uso como agente coagulante para tratamientos de agua.

\section{INTRODUCTION}

Coagulation-flocculation treatment $(\mathrm{CF})$ allows removing organic material from raw and natural water sources to accomplish quality standards for human consumption or industrial applications (Asrafuzzaman et al. 2011). It consists in the addition of chemical substances, such as aluminium-based coagulants that allow the agglomeration of organic material into bigger particles, which can be separated later by solid removal processes (Antov et al. 2010, Gorin et al. 2015). Some disadvantages have been observed regarding the use of chemical coagulants, such as $\mathrm{pH}$ alteration, production of large quantities of slurry, and increases of operation costs (Yin 2010). In addition, aluminium-based coagulants are associated to human diseases, such as Alzheimer due to the presence of residual aluminium in treated waters (Barnard et al. 2014, Di Paolo et al. 2014). Moreover, the use of chemical substances carries environmental consequences, like increasing concentration levels of metals in water and dispersion of acrylamide oligomers, which are also related to health issues (Hernández et al. 2015). These situations demonstrate the need to implement new, low cost, innocuous and environmentally friendly coagulant materials for water treatment and purification (Gorin et al. 2015, Hernández et al. 2015).

There is a new tendency in CF processes that aims towards the use of natural polymers as coagulation agents, thanks to their low acquisition cost and their eco-friendly behavior (Muhammad et al. 2015). Scientists have been able to state that by using natural materials, importation of chemical coagulants could be reduced and even eliminated (Yin 2010, Ramavandi 2014, Yang et al. 2014). The use of natural polymers in CF treatments is widely spread nowadays, and represents a common practice in many water treatment plants at industrialized countries (Yang et al. 2014, Muhammad et al. 2015).

In recent years, there is an increasing interest to find biodegradable materials based on natural polysaccharides for industrial applications and water treatment. Among them, starch emerges as a good candidate, because it comes from agricultural sources and it can be produced at low cost (Muhammad et al. 2015, Ramavandi 2015). The polar nature of starch allows its dispersion in aqueous media, but to achieve a complete dissolution, it is necessary the addition of an alkali compound or a heat treatment, which restrict its application in $\mathrm{CF}$ water treatment (Xu et al. 2004, Pal et al. 2005, Sableviciene et al. 2005). Chemical modification, such as acetylation, arises as an excellent alternative to improve its properties as a coagulant (Xu et al. 2004). Moreover, modification of starch with acetic anhydride molecules increases its solubility in aqueous media, because of the introduction of hydrophilic groups in the starch structure, which leads to increase the number of hydrogen bridges with the surrounding water molecules (Sánchez-Rivera et al. 2010).

In Colombia, especially in the south area of the department of Bolivar, there are some small river towns which keep the tradition of purifying raw water using natural materials like native plantain starch obtained from the species topocho pelipita plantain 
clone (Musa ABB). Sometimes, this alternative becomes the only way to obtain potable water for these rural communities, because they are located in areas of difficult access. Although this ancestral method has been proved to get drinking water, tests have not been performed to confirm the quality of the water after using the starch from the topocho pelipita plantain clone (Musa ABB). It is important to note that this kind of plantain is not used for human consumption due to its hardness, making this biomaterial attractive for the development of natural coagulant materials. This research is focused on the evaluation of the coagulant capacity of the starch obtained from the species topocho pelipita plantain clone (Musa ABB) for turbidity and color removal in raw water. Chemical modification with acetic anhydride was also studied to determine its effect in the water treatment.

\section{MATERIALS AND METHODS}

\section{Materials}

Raw material for starch preparation was obtained from the topocho pelita plantain clone (Musa ABB), which is cultivated in the south area of the department of Bolivar, Colombia. It was used in unripe state, as recommended in the scientific literature (Yang et al. 2014). Acetic anhydride (98\%), sodium hydroxide, chlorhydric acid, and potassium hydroxide were used to prepare acetylated starch. Chemical reagents were purchased from Panreac AppliChem and used as received. Water samples were collected in glass bottles from Canal del Dique in Puerto Badel, Arjona, Bolivar, Colombia.

\section{Extraction of native starch from plantain}

Native starch (NS) was isolated by using the method proposed by Laines et al. (2008). In a typical procedure, $5 \mathrm{~kg}$ of topocho pelipita plantain clone (Musa ABB) were weighted, washed, peeled, and chopped into small cylindrical portions with height of about $2 \mathrm{~cm}$ and a diameter of approximately $1.5 \mathrm{~cm}$. These portions were added to $30 \mathrm{~L}$ of water at $40^{\circ} \mathrm{C}$ for $5 \mathrm{~min}$. They were subsequently submitted to a grinding process using an impact resistant blender until a complete disintegration of the material was achieved. The samples were then washed three times with water. A mesh number 100 was used to eliminate fibbers. This filtered material was stored in a recipient where it settled for 3 hours. The supernatant was separated by decantation, while the sediment was kept under refrigeration at nighttime. The same procedure was executed the next day with an additional removal of supernatant. Afterwards, the final sediment was centrifuged at $8011 \mathrm{~g}$-force for $15 \mathrm{~min}$ to separate water from the pulp. This material was dried in an oven at $40{ }^{\circ} \mathrm{C}$ for $24 \mathrm{~h}$, pulverized into $5 \mathrm{~g}$ portions and finally stored in plastic recipients made of polyethylene terephthalate (PET).

\section{Acetylation of starch}

Chemical modification through acetylation of starch was performed by following the method described by Rendón-Villalobos et al. (2010). In a typical procedure, $40 \mathrm{~g}$ of native starch were mixed with $100 \mathrm{~mL}$ of distilled water and stirred at $250 \mathrm{rpm}$ until a uniform suspension was obtained. Then, this mixture was cooled at $15 \pm 1{ }^{\circ} \mathrm{C}$, and the $\mathrm{pH}$ was adjusted to 8.5 with $\mathrm{NaOH}$ drops at a concentration of $3 \% \mathrm{w} / \mathrm{v}$. Sodium hydroxide acts as catalyst during the acetylation process (Rivas-González et al. 2009). To obtain a suitable chemical modification, acetic anhydride was added slowly (drop by drop) while keeping a constant value of $\mathrm{pH}$ at 8.5. The different levels of acetylation were achieved by adding $5 \mathrm{~mL}$ of acetic anhydride for the low-acetylated starch (LAS) and $15 \mathrm{~mL}$ of acetic anhydride for the high-acetylated starch (HAS). Acetylation reaction was carried out for $5 \mathrm{~h}$ under constant agitation at $200 \mathrm{rpm}$ and room temperature. Afterwards, the excess of alkali was neutralized with the addition of hydrochloride acid [0.5 N] up to obtain an acid media at $\mathrm{pH} 3.0$ (RivasGonzález et al. 2009). The acetylated starches were washed three times with distilled water and once with the ethanol a centrifuge at $693 \mathrm{~g}$-force for 10 min was used. Finally, acetylated starches were dried out in a tray furnace at $40^{\circ} \mathrm{C}$ for $12 \mathrm{~h}$, and stored in ziploc bags.

To determine the acetylation percentage obtained after the chemical treatment, $1 \mathrm{~g}$ of acetylated starch (dry basis) was weighted in a $250 \mathrm{~mL}$ Erlenmeyer flask and $50 \mathrm{~mL}$ of ethanol at $75 \% \mathrm{v} / \mathrm{v}$ were added to the recipient. The Erlenmeyer was then covered and submitted to agitation for $30 \mathrm{~min}$. Forty $\mathrm{mL}$ of a $\mathrm{KOH}[0.5 \mathrm{~N}]$ solution was subsequently added to the mixture, with additional agitation for 72 hours. The saponified samples were titrated with $\mathrm{HCl}[0.5 \mathrm{~N}]$ using phenolphthalein as indicator. After this initial titration, the mixture was left to rest for 2 hours, and then the additional alkali that leached with the sample was titrated as well. The same procedure was performed for the native starch, so that it could be used as reference. Percentage of acetyl groups was calculated according to Equation (1) (Rivas-González et al. 2009, Rendón-Villalobos et al. 2010). 


$$
\begin{gathered}
\text { Acetylation } \\
(\%)
\end{gathered}=\frac{\begin{array}{c}
(m L \text { reference }-m L \text { samples }) \\
\times[\mathrm{HCl}, \mathrm{N}] \times 0.043 \times 100
\end{array}}{\begin{array}{c}
\text { Grams of the sample } \\
(\text { Dray basis })
\end{array}}
$$

Where 0.043 corresponds to the milli-equivalents of the acetyl group. In addition, the degree of substitution (DS) (average number of acetyl groups that are introduced per glucose unit) was calculated using Equation (2) (Rivas-González et al. 2009, RendónVillalobos et al. 2010):

$$
\begin{gathered}
\begin{array}{c}
\text { Degree of } \\
\text { substitution } \\
(\mathrm{DS})
\end{array} \\
\times\left[\begin{array}{c}
162 \times \text { Acetylation }(\%) \\
W \times 100-[\mathrm{Hs}
\end{array}\right.
\end{gathered}
$$

Where, 162 corresponds to the molecular weight of an anhydroglucose unit, $W$ is the molecular weight of the substituent acetyl group (43 $\mathrm{g} / \mathrm{mol})$, and $W_{s}$ is the net increase in molecular weight of the acetyl group minus one $(42 \mathrm{~g} / \mathrm{mol})$.

\section{Characterization of native and acetylated starch}

Chemical structures of NS and the acetylated starch samples (LAS and HAS) were determined by Fourier transform infrared (FTIR) spectroscopy using an IRAffinity-1S Shimadzu spectrophotometer in a wavelength range from 4000 to $600 \mathrm{~cm}^{-1}$. Morphology and size distribution of the prepared starch grains were characterized using a Quanta FEG 650 scanning electron microscope (SEM). For this, a small amount of the characterized starch powder sample was adhered onto a double-sided carbon tape supported to an aluminium sample carrier. Acquisition of the images was performed under low vacuum mode using a large field detector (LFD). Analysis of the samples was executed at an acceleration voltage of $10 \mathrm{KV}$, a spot size of 2 and a work distance (WD) of approximately $8 \mathrm{~mm}$. During this procedure, images were taken from 200 to $100000 \mathrm{X}$.

\section{Experimental design and statistical analysis}

A multilevel general factorial experimental design was used. Type of coagulant and concentration of coagulant were the two factors selected for this study. Three levels were chosen for the first factor: native starch (NS), low acetylated starch (LAS) and high acetylated starch (HAS). On the other hand, five levels were selected for concentration of coagulant: 0 , 50, 100, 150 and $200 \mathrm{mg} / \mathrm{L}$. Experimental tests were carried out by triplicate for a total of 45 samples. Color and turbidity measurements were performed by an Elich colorimeter AQUATESTER and a Merck Turbiquant ${ }^{\circledR} 1100$ turbidimeter, respectively. Statistical analysis was carried out by the STATGRAPHICS Centurion software, Version 16.1.03, through an analysis of variance and correlation between variables within a significance level of $p<0.05$. Color (Pt-Co) and turbidity (NTU) were set as response variables, since those are the main parameters that define water quality (Muhammad et al. 2015).

\section{Evaluation of the coagulant capacity of native and chemically modified starch \\ Coagulation capacity of native and chemically} modified starch was evaluated from the results obtained for color and turbidity removal. For this purpose, the CF process was carried out with a jar test equipment (Yang et al. 2014). This device consisted of five beakers ( $1 \mathrm{~L}$ volume), which were filled with the untreated water. The evaluated coagulant was then added to the beakers at concentrations of 0,50 , 100,150 and $200 \mathrm{mg} / \mathrm{L}$. Afterwards, two agitation stages were performed at $200 \mathrm{rpm}(15 \mathrm{~s})$ and $25 \mathrm{rpm}$ (25 minutes), in order to promote floccule formation (Rivas-González et al. 2009, Rendón-Villalobos et al. 2010). Finally, all mixtures were left to rest for $30 \mathrm{~min}$. Color and turbidity measurements were accomplished using as reference a sample of water treated with commercial aluminium sulphate (AL) at concentrations of $0,15,20,25$ and $30 \mathrm{mg} / \mathrm{L}$. These values were selected because they are close to the ones used in commercial CF processes (Gorin et al. 2015). Results were analysed by a t-student test.

\section{Assessment on the pH behavior}

This parameter was evaluated in order to identify its influence on the CF process. For this purpose, $10 \mathrm{~g}$ of the evaluated starches were mixed with $50 \mathrm{~mL}$ of untreated water. These mixtures were continuously stirred at a moderate rate (no splash) for $5 \mathrm{~min}$. The $\mathrm{pH}$ was measured by a potentiometer. All measurements were performed by triplicate. Results were compared with the $\mathrm{pH}$ of raw water and water treated with commercial AL.

\section{RESULTS}

Percentage of acetyl groups and degree of substitution (DS) of acetylated starch

A significant increase can be seen as a function of the volume of acetic anhydride that is used for 
modification. Low (LAS) and high acetylated starch (HAS) presented significant differences $(\mathrm{p}<0.05)$ regarding content of acetyl groups and degree of substitution (Table I). Proportion of acetyl groups was raised from $18.35 \pm 0.87 \%$ in the LAS sample to $23.74 \pm 0.92 \%$ in the HAS sample. In a similar way, DS increased from $0.8 \pm 0.02$ to $1.22 \pm 0.03$ in the LAS and HAS samples, respectively. This difference was caused by the volume of acetic anhydride that was added during the modification process, which led to a higher number of acetyl groups to be introduced into the starch molecule (Xu et al. 2004, Sánchez-Rivera et al. 2010).

TABLE I. PERCENTAGE OF ACETYLATION AND DEGREE OF SUBSTITUTION

\begin{tabular}{ccc}
\hline Starch sample & Degree of substitution & Acetylation (\%) \\
\hline NS & 0.00 & 0.00 \\
LAS & $0.80 \pm 0.02$ & $18.35 \pm 0.87$ \\
HAS & $1.22 \pm 0.03$ & $23.74 \pm 0.92$ \\
\hline
\end{tabular}

NS $=$ Native starch, LAS $=$ low acetylated starch, HAS $=$ high acetylated starch

Fourier transform infrared (FTIR) spectroscopy

Infrared spectroscopy was used to determine the functional groups that are present in the studied starch samples. Figure 1 shows the presence of peaks at wavelengths that are related to the main chemical groups commonly found within the native and acetylated starch molecules (Mano et al. 2003, Xu et al. 2004). Some of these peaks include vibrations at $3260 \mathrm{~cm}^{-1}, 2900 \mathrm{~cm}^{-1}, 1450 \mathrm{~cm}^{-1}, 1350 \mathrm{~cm}^{-1}$ and $950 \mathrm{~cm}^{-1}$, which are related to stretching of chemical groups within the anhydroglucose unit of the starch molecule ( $\mathrm{Xu}$ et al. 2004), such as- $\mathrm{OH},-\mathrm{CH}, \mathrm{CO}-\mathrm{H}$ bending, $-\mathrm{CO}$ stretching, and $\mathrm{C}-\mathrm{O}-\mathrm{C}$ bending, respectively (Stuart 2004).

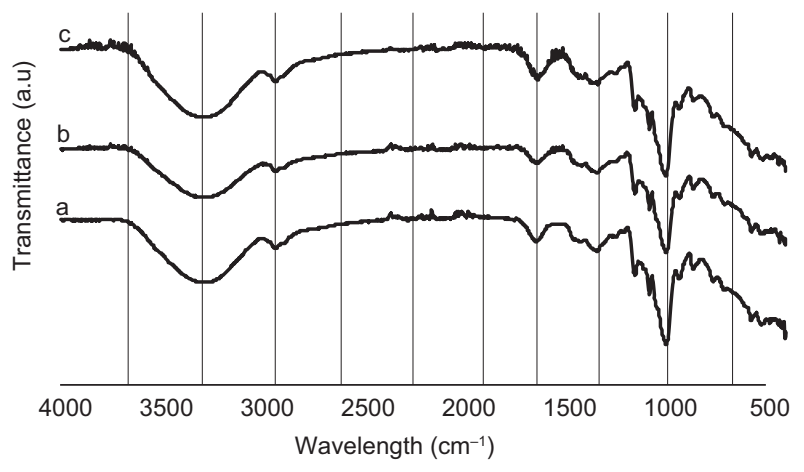

Fig. 1. Fourier transform infrared spectroscopy for starch samples: a) native starch, b) low acetylated starch and c) high acetylated starch

\section{Scanning electron microscope (SEM)}

Figure 2 shows the SEM micrography that was taken for native starch (NS), low acetylated starch (LAS) and high acetylated starch (HAS). It can be observed that starch granules presented a smooth and polished surface with an apparent softness and irregular, enlarged, oval-shapes. It also shows a truncated end, similar to the ones reported in the literature $(\mathrm{Xu}$ et al. 2004, Singh et al. 2011). The ImageJ software provided by the National Institutes of Health (NIH) was used to determine the size distribution of the studied starch grains. For this measurement, it was counted 100 grains per sample. Average sizes of 37 $\pm 8 \mu \mathrm{m}$ were estimated for the NS sample, $35 \pm 11$ $\mu \mathrm{m}$ for the LAS sample, and $307 \pm 85 \mu \mathrm{m}$ for the HAS sample. Large sizes observed in the sample with higher degree of substitution can be attributed to agglomeration of grains during the modification process with acetic anhydride (Xu et al. 2004, RivasGonzález et al. 2009, Rendón-Villalobos et al. 2010).

\section{Color and turbidity removal}

Analysis of variance evidenced that concentration was the only factor with statistically significant effects on the response variables (color and turbidity

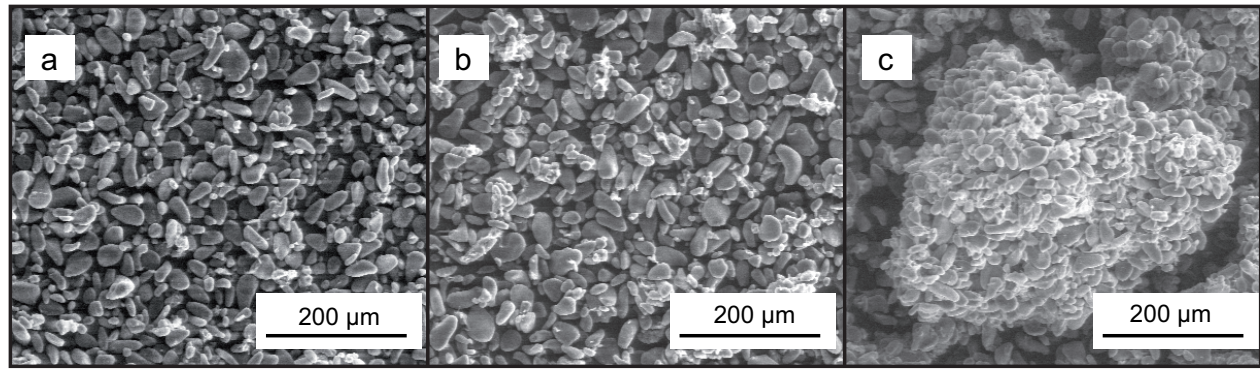

Fig. 2. Scanning electron microscope photographs of the a) native starch, b) low acetylated starch and c) high acetylated starch 
removal) at a confidence level of $95 \%$. After this evaluation, it was determined by the platinum-cobalt (Pt-Co) method, that water with the least amount of coloration was the one treated with NS sample, while the one treated with the HAS sample showed the highest values (Fig. 3). Although, turbidity measurements for the treatments are within statistical error of each other, there appears to be a declining trend as seen with the color measurements (Fig. 4).

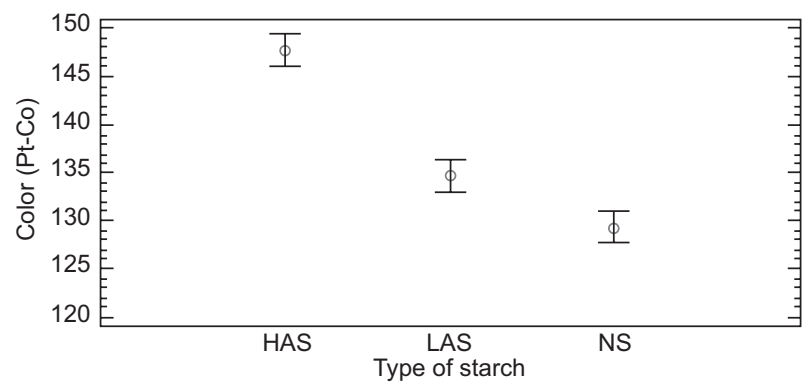

Fig. 3. Color remaining in raw water samples after using native starch (NS) and acetylated starches with low (LAS) and high (HAS) degree of substitution. Error bars represent standard error from the mean

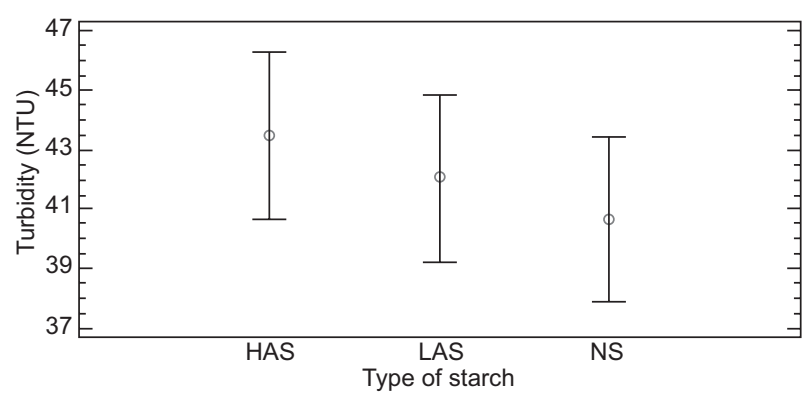

Fig. 4. Turbidity remaining in raw water samples after using native starch (NS) and acetylated starches with low (LAS) and high (HAS) degree of substitution. Error bars represent standard error from the mean

Table II shows the percentages of color and turbidity removal obtained for the analysed samples, including a commercial AL sample. Hernández et al. (2015) evaluated the application of tamarindo seeds (Tamarindus indica L.) for turbidity and color removal in raw water. The authors achieved a high removal efficiency with this coagulant, obtaining for a concentration of $110 \mathrm{mg} / \mathrm{L}$ of the seeds, a turbidity removal of $99.71 \%$ along with a color removal of $99.60 \%$. Asrafuzzaman et al. (2011) evaluated the efficiency of turbidity removal using seeds of Moringa oleifera, reporting efficiencies up to $95.89 \%$, which is also closer to the ones that were achieved in this research.
TABLE II. PERCENTAGES OF COLOR AND TURBIDITY REMOVAL IN THE ANALYSED SAMPLES

\begin{tabular}{lccc}
\hline Coagulant & $\begin{array}{c}\text { Concentration } \\
(\mathrm{mg} / \mathrm{L})\end{array}$ & $\begin{array}{c}\text { Color } \\
\text { removal }(\%)\end{array}$ & $\begin{array}{c}\text { Turbidity } \\
\text { removal }(\%)\end{array}$ \\
\hline \multirow{4}{*}{$\mathrm{AL}$} & 0 & 0.00 & 0.00 \\
& 5 & 79.59 & 54.85 \\
& 10 & 84.69 & 86.35 \\
& 15 & 97.96 & 99.99 \\
& 20 & 98.98 & 99.99 \\
\hline \multirow{2}{*}{ NS } & 0 & 0.00 & 0.00 \\
& 50 & 90.94 & 95.69 \\
& 100 & 91.95 & 95.81 \\
& 150 & 92.95 & 96.21 \\
& 200 & 93.96 & 96.33 \\
\hline \multirow{4}{*}{ LAS } & 0 & 0.00 & 0.00 \\
& 50 & 88.85 & 93.16 \\
& 100 & 89.86 & 94.48 \\
& 150 & 91.89 & 94.94 \\
& 200 & 92.91 & 95.64 \\
\hline \multirow{4}{*}{ HAS } & 0 & 0.00 & 0.00 \\
& 100 & 86.82 & 90.48 \\
& 150 & 87.84 & 92.77 \\
& 200 & 88.85 & 94.15 \\
& & & 95.00 \\
\hline
\end{tabular}

$\mathrm{AL}=$ commercial aluminium sulphate, $\mathrm{NS}=$ native starch, $\mathrm{LAS}$ = low acetylated starch, HAS $=$ high acetylated starch

\section{pH behavior}

Table III shows the results that were obtained for $\mathrm{pH}$ measurements in the studied suspensions. There were statistically significant differences $(\mathrm{p}<$ 0.05 ) between them. Initial $\mathrm{pH}$ of the water sample was 6.33. The aluminium dose slightly lowered this value to 6.31 . However, all of the suspensions showed $\mathrm{pH}$ values that were within the optimum range for CF processes (Choy et al. 2015, Gorin et al. 2015).

TABLE III. pH VALUES OBTAINED FOR THE TESTED STARCHES SAMPLES AND A COMMERCIAL ALUMINIUM SULPHATE SAMPLE

\begin{tabular}{cc}
\hline Suspension & pH value \\
\hline Raw water & $6.33 \pm 0.19^{\mathrm{a}}$ \\
AL & $6.31 \pm 0.11^{\mathrm{b}}$ \\
NS & $6.68 \pm 0.16^{\mathrm{c}}$ \\
LAS & $6.72 \pm 0.17^{\mathrm{d}}$ \\
HAS & $6.75 \pm 0.15^{\mathrm{e}}$ \\
\hline
\end{tabular}

$\mathrm{AL}=$ commercial aluminium sulphate, $\mathrm{NS}=$ native starch, LAS $=$ low acetylated starch, HAS = high acetylated starch. Superscript letters indicate statistically significant differences at a 0.05 level 


\section{DISCUSSION}

\section{Percentage of acetyl groups and degree of substi- tution (DS) of acetylated starch}

Rendón-Villalobos et al. (2010) reported the acetylation of Musa paradisiaca L. plantain species. In that work, the authors achieved degrees of substitution of 0.56 and 1.05 at low and high levels of acetylation, respectively. Acetylation percentages corresponding to those results were $12.90 \%$ and $21.93 \%$, respectively. In a different study using the same plantain species, Rivas-González et al. (2009) reported degrees of substitution and maximum acetylation percentages of $1.09 \%$ and $22.58 \%$, respectively. However, the percentages and degrees of substitution were higher in this work, thus proving the versatility of the method that was implemented. Even though all of the compared results are below the ones that were obtained in the current research, it must always be taken into consideration that both, acetylation percentage and degree of substitution depend on the vegetal source and granular structure of the native starch (Xu et al. 2004, Sánchez-Rivera et al. 2010).

\section{Fourier transform infrared (FTIR) spectroscopy}

After acetylation of plantain starch with acetic anhydride, Rivas-González et al. (2009) reported the presence of a vibrational peak at a wavelength of $1740 \mathrm{~cm}^{-1}$, which is characteristic of the acetyl group $-\mathrm{C}=\mathrm{O}$ that is introduced into the polymeric chains of starch. It was not possible to identify the presence of this peak in the studied samples of the modified starch, since a wide peak was obtained between 1750 and $1600 \mathrm{~cm}^{-1}$, with a maximum transmittance at $1650 \mathrm{~cm}^{-1}$. This suggests the presence of water molecules within the evaluated samples (NS, LAS, and HAS), which can be confirmed by the peak at $3300 \mathrm{~cm}^{-1}$ which is commonly attributed to stretching of $-\mathrm{OH}$ groups that are also present in the water molecule (Berzina-Cimdina and Borodajenko 2012). The hygroscopic property of the material and high humidity of the area could explain the presence of water in its composition (Mei et al. 2013). Nonetheless, it was possible to observe a higher intensity peak between 1750 and $1600 \mathrm{~cm}^{-1}$ as a function of the acetylation percentage of starch. Some other changes in intensity were also observed in peaks that are characteristics of anhydrides, such as the one at $1150 \mathrm{~cm}^{-1}$ that is related to the stretching bond of $-\mathrm{CO}$ group. This confirms that acetylation was achieved in the plantain starch, as reported by other authors in similar studies (Adebajo and Frost 2004, Xu et al. 2004, Xu and Hanna 2005, Bello et al. 2010).

\section{Scanning electron microscope (SEM)}

As evidenced in figure 2, size and shape of the LAS showed slight variations when compared to NS. On the other hand, HAS presented a significant change, showing an evident and bigger merging of grains. This can be attributed to the higher introduction of hydrophilic groups into the starch structure during the chemical modification, which leads to the increase in the number of hydrogen bridges between these modified grains (Xu et al. 2004, Xu and Hanna 2005). SEM photographs of the acetylated starch clearly show that the number of merged granules increases with high acetylation levels and degrees of substitution. In addition, a slight gradual surface damage started to be observed for the high acetylated starch sample (HAS). Although it has been reported that the acetylation of the starch allows an increase on its coagulant activity in the CF application, it is possible that the introduction of this chemical group into the starch structure can affect its integrity, changing its mechanical properties (Xu et al. 2004, Bello et al. 2010).

\section{Color and turbidity removal}

Regarding the results displayed in table II, it is not necessary to perform an acetylation treatment of the starch to achieve a suitable color and turbidity removal from raw water, as the highest removals values were obtained using starch in its native condition $(93.96 \%$ and $96.33 \%$, respectively using native starch at concentration of $200 \mathrm{mg} / \mathrm{L}$ ). LAS showed a similar behavior than native starch (NS) for color and turbidity removal, obtaining values of $92.91 \%$ for color removal and $95.64 \%$ for turbidity removal using a concentration of $200 \mathrm{mg} / \mathrm{L}$. On the other hand, HAS showed a decrease for color removal at the same concentration of $200 \mathrm{mg} / \mathrm{L}$, displaying a value of $88.85 \%$. It is possible that HAS sample has a more electronegative surface than LAS sample, as more acetyl groups were incorporated in its structure (Sánchez-Rivera et al. 2010). These electronegative groups can repeal molecules with negative charge, such as organic acids that are present in naturally colored waters. For example, humic and fulvic acids are large macromolecules with negative charge, due to the presence of carboxylic groups in their chemical structures (Crittenden et al. 2012), so it is possible that these molecules would have less affinity with the high acetylated starches.

On the other hand, when compared to the commercial AL, color and turbidity removal was higher using AL reagent even in a low concentration of $20 \mathrm{ppm}$, than the ones obtained after using the native starch at $200 \mathrm{ppm}$. High concentrations of starch can hinder the effectiveness of flocculation. This is due to the fact 
that starch covers completely the surface of the particles, which prevents the creation of bridges between them (Dogu and Arol 2004, Yang et al. 2014). This behavior is similar to the one reported by Shamsnejati et al. (2015), who evaluated the coagulant capacity of basil (Ocimum basilicum L.) for color removal using wastewater samples from the textile industry. They found that this biomass was very efficient, observing a color removal efficiency of about $68.5 \%$ with the use of $1.6 \mathrm{mg} / \mathrm{L}$ of the coagulant.

Previous studies have shown that the use of natural coagulants, such as native and chemically modified starch, yields suitable results for $\mathrm{CF}$ water treatment (Xu et al. 2004, Xu and Hanna 2005, Sánchez-Rivera et al. 2010). However, this study indicates that there is no need to modify native plantain starch. Hence, ancestral customs from the river towns of the department of Bolivar, Colombia are proven to be adequate regarding the use of natural materials to purify water, making it easier for them to access such a vital and difficult resource in that area.

When selecting the most suitable treatments, NS starch at $150 \mathrm{mg} / \mathrm{L}$ was selected as the best one by considering the removal results that it achieved. Using $200 \mathrm{mg} / \mathrm{L}$ did not caused any significant difference on the removal percentages. On the contrary, it represented a major spending of raw matter. Therefore, $150 \mathrm{mg} / \mathrm{L}$ is also the appropriate choice in terms of efficiency. In the same way, $15 \mathrm{mg} / \mathrm{L}$ was chosen as optimum concentration for AL sample. A t-student test was achieved to compare the results in both types of coagulants, the analysis showed that the average response of each treatment was different.

The world health organization (WHO) has established among the quality parameters for water to be used for human consumption a turbidity (NTU) value between 1 to 5 and a color ( $\mathrm{Pt}-\mathrm{Co}$ ) value under 40 (WHO 1997). Regarding this, Muhammad and Sasikala (2014) used watermelon seeds as natural coagulants for water treatment. Although, the authors reported a decrease in turbidity at 0.89 NTU, the change in color value was $15 \mathrm{Pt}-\mathrm{Co}$, which is higher than the value allowed for the WHO. On the other hand, we obtained a minimum turbidity level at about 6.44 NTU and color values of $30 \mathrm{Pt}-\mathrm{Co}$ for the evaluated starches. Even though these results do not fulfil the WHO requirements, they are acceptable since these values are commonly obtained in processes of clarification of high turbidity water (Sivakumar 2013, Tassinaria et al. 2013). Application of this method could be considered using some other varieties of plantains, as well as different natural products that are typical from the Caribbean region at Colombia.
Mixing with additional coagulants for water treatment could be considered as well. It should be noticed that this research ultimately evaluates the CF stage, and that an additional filtration process could yield better results, since CF represents only a primary treatment (Sivakumar 2013).

\section{pH behavior}

Starch has a negative charge, and a low $\mathrm{pH}$ implicates a positive charge in the superficial sites, which promote the adsorption of starch (Trujillo et al. 2014). High values of $\mathrm{pH}$ indicate a negative charge in superficial sites, which leads to starch degradation (Tassinaria et al. 2013, Yang et al. 2014). The phenomenon that is presented in this research could be explained by keeping in mind the statement above. According to this, low $\mathrm{pH}$ promotes turbidity and color removal when natural coagulants like starch are used (Yang et al. 2014, Muhammad et al. 2015). Therefore, high removal values are expected to take place with low acetylated starch. It must also be considered that $\mathrm{pH}$ not only affects the chemical equilibrium of formation of complex ions in the coagulant agent, but also the solubility conditions according to the type of starch that is used in each study (Muhammad et al. 2015).

\section{CONCLUSIONS}

It was reported the possibility to obtain starch from the topocho pelipita plantain clone (Musa $\mathrm{ABB}$ ) yielding an $87 \%$ of extraction from an easy and economical route. Moreover, it was determined that there is not necessary to perform a chemical modification of the native plantain starch to achieved acceptable values for color and turbidity removal in raw water samples. Hence, ancestral customs from river towns placed at the south part of the Bolivar department in Colombia, are proven to be adequate regarding the use of natural materials to purify water. Additionally, it is important to highlight the health benefits of using native starch as biomaterial for this kind of processes, when compared to the commercial aluminium sulphate coagulant that is currently being used in water treatment in Colombia.

\section{ACKNOWLEDGMENTS}

The authors are grateful to Universidad de Cartagena for the scholarship given to the Food Engineer Diego Felipe Tirado Armesto during his study at the Master of Environmental Engineering Program. 
Additionally, we would like to thank professors Sandra Correa-Torres from the Universidad Pontificia (Bucaramanga, Colombia) and Jorge Sánchez-Toro from the Universidad Pontificia (Medellin, Colombia) for their collaboration regarding the scanning electron microscope (SEM) and Fourier transform infrared (FTIR) spectroscopy measurements.

\section{REFERENCES}

Adebajo M. O. and Frost R. L. (2004). Acetylation of raw cotton for oil spill cleanup application: an FTIR and 13 C MAS NMR spectroscopic investigation. Spe. Acta Part A: Molec. and Bio. Spect. 60, 2315-2321. DOI: $10.1016 /$ j.saa.2003.12.005

Antov M., Siban M. and Petrovis N. (2010). Protein from common bean (Phaseolus vulgaris) seed as a natural coagulant for potential application in water turbidity removal. Bio. Tech. 101, 2167-2172.

DOI: 10.1016/j.biortech.2009.11.020

Asrafuzzaman M., Fakhruddin A. N. and Hossain M. A. (2011). Reduction of turbidity of water using locally available natural coagulants. ISRN. Microb. 2011, 1-6. DOI: $10.5402 / 2011 / 632189$

Barnard N., Bush A., Ceccarelli A., Cooper J., Jager De C., Erickson K. and Squitti R. (2014). Dietary and lifestyle guidelines for the prevention of alzheimer's disease. Neu. of Aging 35, 74-78.

DOI: 10.1016/j.neurobiolaging.2014.03.033

Bello L. A., Sánchez-Rivera M. M., Núñez-Santiago C., Rodríguez-Ambriz S. L. and Román-Gutiérrez A. D. (2010). Effect of the pearled in the isolation and the morphological, physicochemical and rheological characteristics of barley starch. Carb. Poly. 81, 63-69. DOI: 10.1016/j.carbpol.2010.01.056

Berzina-Cimdina L. and Borodajenko N. (2012). Research of calcium phosphates using fourier transform infrared spectroscopy. In: Infrared spectroscopy - Materials science, engineering and technology. (T. Theophile, Ed.). InTech, Rijeka, Croatia, pp. 123-148.

DOI: $10.5772 / 36942$

Choy S. Y., Prasad K. M. N., Wu T. Y. and Ramanan R. N. (2015). A review on common vegetables and legumes as promising plant-based natural coagulants in water clarification. Int. J. of Env. Sci. and Tech. 12, 367-390. DOI: $10.1007 / \mathrm{s} 13762-013-0446-2$

Crittenden J. C., Trussell R. R., Hand D.W., Howe K.J. and Tchobanoglous G. (2012). MWH's Water treatment: Principles and design. 3th. Ed. John Wiley and Sons. Washington, USA, $1920 \mathrm{pp}$.

Di Paolo C., Reverte I., Colomina M., Domingo J. and Gómez M. (2014). Chronic exposure to aluminum and melatonin through the diet: neurobehavioral effects in a transgenic mouse model of alzheimer disease. F. and. Chem. Tox. 69, 320-329.

DOI: $10.1016 /$ j.fct.2014.04.022

Dogu I. and Arol A. I. (2004). Separation of dark-colored minerals from feldspar by selective flocculation using starch. Pow. Techn. 139, 258-263.

DOI: 10.1016/j.powtec.2003.11.009

Gorin K. V., Sergeeva Y. E., Butylin V. V., Komova A. V., Pojidaev V. M., Badranova G. U., Shapovalova A. A., Konova I. A. and Gotovtsev P. M. (2015). Methods coagulation/flocculation and flocculation with ballast agent for effective harvesting of microalgae. Bio. Tech. 193, 78-184. DOI: 10.1016/j.biortech.2015.06.097

Hernández B., Mendoza I., Salamanca M., Fuentes L. and Caldera Y. (2015). Tamarind seeds (Tamarindus indica) as a coagulant in highly turbid water. Redieluz 3, 91-96.

Laines J. R., Goñi J. A., Adams R. H. and Camacho W. (2008). Mezclas con potencial coagulante para tratamiento de lixiviados de un relleno sanitario. Interciencia 33, 22-28.

Mano J. F., Koniarova D. and Reis R. L. (2003). Thermal properties of thermoplastic starch/synthetic polymer blends with potential biomedical applicability. J. of Mat. Scie. Mat. in Med. 14, 127-135.

DOI: 10.1023/A:1022015712170

Mei J., Yuan Y., Guo Q., Wu Y., Li Y. and Yu H. (2013). Characterization and antimicrobial properties of water chestnut starch-chitosan edible films. Int. J. Biol. Macromol. 61, 169-174.

DOI: 10.1016/j.ijbiomac.2013.06.026

Muthuraman G. and Sasikala S. (2014). Removal of turbidity from drinking water using natural coagulants. J. of Ind. and Eng. Chem. 20, 1727-1731.

DOI: 10.1016/j.jiec.2013.08.023

Muhammad S. A., Abdulkarim A. and Bello I. M. (2015). Water melon seed as a potential coagulant for water treatment. Glob. J. of. Res. In Eng. 15, 16-23.

Ramavandi B. (2014). Treatment of water turbidity and bacteria by using a coagulant extracted from Plantago ovata. Wat. Res. and. Ind. 6, 36-50.

DOI: 10.1016/j.wri.2014.07.001

Pal S., Mal D. and Singh R. (2005). Cationic starch: an effective flocculating agent. Car. Poly. 59, 417-423. DOI: 10.1016/j.carbpol.2004.06.047

Rendón-Villalobos R., García-Hernández E., GueizadoRodríguez M., Salgado-Delgado R. and RangelVázquez N. A. (2010). Preparation and characterization of banana starch (Musa paradisiaca L.) acetylated to different degrees of substitution. AFINIDAD 67, 294-300.

Rivas-González M., Zamudio-Flores P. B. and Bello-Pérez L. A. (2009). Effect of the acetylation degree on the 
morphological and physicochemical characteristics of banana starch. Rev. Mex. de Ing. Quím. 8, 291-297.

Sableviciene D., Klimaviciute R., Bendoraitiene J. and Zemaitaitis A. (2005). Flocculation properties of highsubstituted cationic starches. Col. and sur. 259, 23-30. DOI: 10.1016/j.colsurfa.2005.02.004

Sánchez-Rivera M. M., Flores-Ramírez I., Zamudio-Flores P. B., González-Soto R. A., Rodríguez-Ambrí S. A. and Bello-Pérez L. A. (2010). Acetylation of banana (Musa paradisiaca L.) and maize (Zea mays L.) starches using a microwave heating procedure and iodine as catalyst: Partial characterization. Starch 62, 155-164. DOI: 10.1002/star.200900209

Shamsnejati S., Chaibakhsh N., Pendashteh A. R. and Hayeripour S. (2015). Mucilaginous seed of Ocimum basilicum as a natural coagulant for textile wastewater treatment. Ind. Crops and Prod. 69, 40-47. DOI: $10.1016 /$ j.indcrop.2015.01.045

Sivakumar D. (2013). Adsorption study on municipal solid waste leachate using Moringa oleifera seed. Int. J. of Env. Scie. and Techn. 10, 113-124. DOI: $10.1007 /$ s13762-012-0089-8

Singh A. V., Nath L. K. and Guha M. (2011). Synthesis and characterization of highly substituted acetylated moth bean starch. J. of Poly. Mat. 28, 277-285.

DOI: $10.1002 /$ star.201100012

Stuart B. H. (2004). Infrared spectroscopy: Fundamentals and applications. John Wiley and Sons. Sydney, Australia, $221 \mathrm{pp}$.

Tábi T. and Kovács J. B. (2007). Examination of injection moulded thermoplastic maize starch. eXPRESS Polymer Letters 1, 804-809.

DOI: 10.3144/expresspolymlett.2007.111
Tassinaria B., Dohertya S. and Marisona I. W. (2013). Submicron capsules extracted from rapeseed as novel flocculant agents for the treatment of turbid water. Water. Res. 47, 4957-4965. DOI: 10.1016/j.watres.2013.05.033

Trujillo D., Duque L. F., Arcila J. S., Rincón A., Pacheco S. and Herrera O. F. (2014). Turbidity removal in a water sample from a natural source via coagulation/ flocculation using plantain starch. ION 27, 17-34.

WHO (1997). Guidelines for drinking-water quality. 2nd Ed. Surveillance and control of community supplies. World Health Organization. Geneva, Switzerland, $250 \mathrm{pp}$.

Xu Y., Miladinov V. and Hanna M. A. (2004). Synthesis and characterization of starch acetates with high substitution. Cer. Chem. 81, 735-740.

Xu Y. and Hanna M. A. (2005). Preparation and properties of biodegradable foams from starch acetate and poly (tetramethylene adipate-coterephthalate). Car. Poly. 59, 521-529. DOI: 10.1016/j.carbpol.2004.11.007

Yang C., Yeong T. and Ching J. (2014). Optimization of agro-industrial wastewater treatment using unmodified rice starch as a natural coagulant. Ind. Crops. and. Prod. 56, 17-26. DOI: 10.1016/j.indcrop.2014.02.018

Yin C. (2010). Emering usage of plant-based coagulants for water and wastewater treatment. Proc. Bioch. 45, 1437-1444. DOI: 10.1016/j.procbio.2010.05.030 